\title{
IMPORTANCE OF IONIC AND OSMOTIC COMPONENTS OF SALT STRESS ON THE GERMINATION OF FOUR QUINUA (Chenopodium quinoa Willd.) SELECTIONS
}

\author{
José Delatorre-Herrera $^{1 *}$, and Manuel Pinto ${ }^{2}$
}

\begin{abstract}
The influence of the components of saline stress (osmotic and ionic factors) were evaluated during the germination of four quinua (Chenopodium quinoa Willd.) selections in Chile, two collected in the arid northern highland region with saline soils (Amarilla and Roja) and the other two from the rainy southern region with non-saline soils (Hueque and Pucura). The seeds were treated with different saline concentrations $(0,0.2,0.4,0.8$ and $1.2 \mathrm{M} \mathrm{NaCl})$. Germination kinetics shows that the control treatments of the four selections reach $100 \%$ germination. With application of $0.4 \mathrm{M}$ $\mathrm{NaCl}\left(\mathrm{LD}_{50 \max }\right)$ germination was reduced by $53 \%$ in the Amarilla selection and $89.9 \%$ in Hueque. The germination rate was lower for the seeds from non-saline areas, which reached germination after $22 \mathrm{~h}$, compared to $10 \mathrm{~h}$ for Amarilla. By separating the salinity stress factors (osmotic and ionic), it is evident that they have different degrees of influence on quinua germination, according to each selection. Thus, the germination of Amarilla selection from the arid area was the least influenced by the ionic factor (27\%), Pucura and Roja were more affected by the ionic factor ( $40 \%$ and $46 \%$ respectively), and Hueque, from the rainy area, was more affected by the osmotic factor, in which caused a $50 \%$ loss in germination.
\end{abstract}

Key words: Chenopodium, salinity, imbibition, seeds, $\mathrm{NaCl}$, altiplano, desert.

\section{INTRODUCTION}

Glycophyte plants have low levels of tolerance to saline stress. For example, an increase in salinity from 0 to 180 $\mathrm{mM}$ of $\mathrm{NaCl}$ decreases germination by $50 \%$ in species of the genus Phaseolus (Bayuelos et al., 2002). In contrast, halophyte plants are more tolerant to salinity. For example, Cakile maritima Scop. can support a concentration of salts close to $400 \mathrm{mM}$ of $\mathrm{NaCl}$ without showing effects in $80 \%$ of its germination. High concentrations of $\mathrm{NaCl}$ induce dormancy in the seeds of many halophyte species (Gul and Weber, 1998; Debez et al., 2004), while seeds of glycophyte species loss their viability under similar conditions. Nevertheless, germination in both halophyte and glyophyte plants is sensitive to salinity (Pujol et al., 2000). The velocity of germination is one aspect that is affected. For example, in $C$. maritime, germination begins 4 days later with treatments of $400 \mathrm{mM}$ than with treatments of lower concentrations (Debez et al., 2004).

\footnotetext{
'Universidad Arturo Prat, Departamento de Agricultura del Desierto y Biotecnología, Casilla 121, Iquique, Chile. "Corresponding author (jose.delatorre@unap.cl).

${ }^{2}$ Universidad de Chile, Facultad de Ciencias Agronómicas, Casilla 1004, Santiago, Chile.

Received: 05 May 2008.

Accepted: 23 September 2008.
}

Several authors have shown that the decrease in seed germination caused by salinity is the result of the joint action of two types of stress factors: water deficit produced by the osmotic effect of salts in the soil solution, also termed "osmotic dehydration", and toxicity as a consequence of the excessive intake of ions such as $\mathrm{Cl}^{-}$and $\mathrm{Na}^{+}$in tissues (Munns et al., 1995; Zhu, 2003). During germination, the joint action of the two stresses is manifested as a decrease in the percentage and velocity of germination (Huang and Redmann, 1995; Ungar, 1996; Kerepesi and Galiba, 2000). In halophyte plants the decrease in germination is mainly the consequence of lower osmotic potentials in the soil solution, given that ion intake by seeds can be limited or harmless, while in glycophytes, the excessive accumulation of ions in tissue causes nutritional imbalance, toxicity and finally death (Munns et al., 1995; Katambe et al., 1998; Dodd and Donovan, 1999). Thus, the differences in germination observed between the seeds of tolerant and sensitive plants could be the results of the activation of different mechanisms (Dodd and Donovan, 1999; Kerepesi and Galiba, 2000; Almansouri et al., 2001) of cells from the different parts of the embryonic axis in order to tolerate both osmotic and ionic stress during germination. The relative importance of the two stresses has not been well 
studied in species such as quinua, which is characterized by its adaptability to different edaphic conditions and tolerance to salinity (Jacobsen et al., 1999; Mujica et al., 2001).

This species has been cultivated for centuries in the desert of northern Chile in soils with high salinity, with electrical conductivity (EC) that can reach values close to $10 \mathrm{dS} \mathrm{m}^{-1}$ (Delatorre et al., 1995). However, using a cultivar from the central-southern region of Chile, and therefore possibly adapted to soils with low EC, Karyotis et al. (2003) observed that an ED higher than $6.5 \mathrm{dS} \mathrm{m}^{-1}$ reduces germination in these accessions by $70 \%$. The contrast in the response to salinity between selections from northern and southern Chile is probably the consequence of adaptations achieved over time by populations that developed in isolation from one another under very different environmental conditions. This has induced some degree of genetic distancing among these populations, segregating them into two discrete groupings. This segregation has broad agricultural implications, in particular in the adaptability that they have developed to their respective environments (Fuentes et al., 2005; 2008). Consequently, it is possible that the quinua populations from the north are closer to halophytes or facultative halophytes, as described by Bosque et al. (2003), while the selections from the south could be closer to glycophyte plants.

In consideration of this background information, it can be argued that during quinua germination there are differences in levels of susceptibility to salinity between selections acclimatized to the arid and saline conditions of the altiplano and selections adapted to the conditions of high precipitation and non-saline soils of southern Chile. These differences could be expressed in the germination percentages and rates and the relative importance of the two components involved in salinity (osmotic and ionic factors). The main objective of the present work was to establish the effect of saline stress on germination, as well as the relative importance of the component factors of this stress, ionic and osmotic stress, on four selections of quinua from two contrasting agro-ecological conditions, namely the northern high Andes and salt flats on the one hand, and the humid southern Chilean region with nonsaline soils found at sea level.

\section{MATERIALS AND METHODS}

Seeds from four selections of quinua: Amarilla and Roja from the altiplano region of northern Chile $\left(19^{\circ} 28^{\prime}\right.$ $\mathrm{S}, 68^{\circ} 50^{\circ} \mathrm{W}$ ), and Hueque and Pucura from Temuco $\left(38^{\circ} 43^{\prime} \mathrm{S}, 72^{\circ} 32^{\prime} \mathrm{W}\right)$ in southern Chile, were germinated on Whatman 42 filter paper in Petri dishes of $10 \mathrm{~cm}$ in diameter, embedded in $10 \mathrm{~mL} \mathrm{NaCl}$ solutions with the following concentrations: $0 ; 0.2 ; 0.4 ; 0.8$ and $1.2 \mathrm{M}$. There were five replicates of each treatment, each of which corresponded to a Petri dish with 100 seeds. The seeds were incubated for $22 \mathrm{~h}$ at $25{ }^{\circ} \mathrm{C}$ in darkness in a germination chamber (Incubator 865, Precision Scientific, Chenai, India). Responses were measured in terms of the percentage of germination, which was considered as the presence of radicula of more than $0.5 \mathrm{~mm}$. NaCl (Hach Company, Loveland, Colorado, USA) was used for preparation of the saline solutions at $99.9 \%$ of purity with de-ionized distilled water. Seed counts were made at 2 , $4,6,10,14,18$ and $22 \mathrm{~h}$ after seeding. The germination kinetics and germination velocity for each selection were obtained from this information, in accordance with the method of Khan and Ungar (1984).

Based on the final germination values, the saline concentration was determined that reduced germination in each selection by $50 \%$. This value is termed $\mathrm{LD}_{50}$. This range was established considering the requirement that the genotypes used express the effects of germination on salts at non-lethal concentrations. To separate the ionic and osmotic effects, the concentration was used that reduced germination by $50 \%$ in the most tolerant selection, termed $\mathrm{LD}_{50 \max }$, with the aim that this selection could express both the morphological and biochemical effects of salts.

To determine the $\mathrm{Na}$ content, all the germinated seeds in each replicate were collected, dried at $70{ }^{\circ} \mathrm{C}$ for $48 \mathrm{~h}$ and then milled. Na was measured according to the procedure described by Hunt (1982). A sample of 0.1 $\mathrm{g}$ was digested in $15 \mathrm{~mL}$ of $\mathrm{HCl} 0.5 \mathrm{M}$ for 2 days. $\mathrm{Na}$ concentration was determined with a flame photometer (PFP7 Jenway, Gransmore, England). The osmotic potential $\left(\psi_{\mathrm{s}}\right)$ of the seeds was determined by macerating $0.1 \mathrm{~g}$ of dry matter (DM) obtained from the complete seed previously congealed liquid $\mathrm{N}$ in $1 \mathrm{~mL}$ of nanopure water. The extract was centrifuged and an aliquot of supernatant was injected into an osmometer (3000 model, Advance, Norwood, Massachusetts, USA). The calculation of $\psi_{\mathrm{s}}$ was obtained through the Van't Hoff Equation [1]:

$$
\psi_{\mathrm{s}}=\mathrm{C} * \mathrm{~T} * \mathrm{R}
$$

where $\mathrm{C}$ corresponds to the concentration or osmolality (mOsmol kg-1 $\mathrm{H}_{2} \mathrm{O}$ ) determined with an osmometer, $\mathrm{T}$ is the absolute temperature and $\mathrm{R}$ is the gas constant $\left(0.00831 \mathrm{MPa} \mathrm{mol}^{-1}{ }^{\circ} \mathrm{K}^{-1}\right)$.

\section{Determination of the ionic and osmotic effects}

According to Munns et al. (1995), the decrease in germination under saline conditions is the consequence of the combined effect of osmotic and ionic factors; consequently the total effect (TE) of salinity on germination can be defined as: 


$$
\mathrm{TE}=\mathrm{OE}+\mathrm{IE}
$$

where it is deduced that the osmotic (OE) or ionic effects (IE) corresponds in turn to the subtraction of the complement corresponding to each one in relation to the total effect (TE).

To resolve this equation, the osmotic components (EO) were separated, which were determined by germinating seeds in distilled water (zero osmolality) and in an isotonic solution of polietilenglycol (PEG 8000) with an osmolality equivalent to that of $0.4 \mathrm{M} \mathrm{NaCl}\left(\mathrm{LD}_{50 \max }\right)$ or $658 \mathrm{mOsmol} \mathrm{kg}{ }^{-1}$. Consequently, $\mathrm{OE}$ corresponds to the difference between the germination values obtained under pure water conditions $\left(\mathrm{G}_{\mathrm{H} 2 \mathrm{O}}\right)$ and those obtained in the isotonic solution $\left(\mathrm{G}_{\mathrm{OS}}\right)$.

$$
\mathrm{OE}=\mathrm{G}_{\mathrm{H} 2 \mathrm{O}}-\mathrm{G}_{\mathrm{Os}}
$$

An osmometer was used according to the procedure already described in order to determine the osmolality of each saline solution.

The total effect (TE) of salinity, or the combined osmotic and ionic effect, is obtained by means of the difference between the germination values under nonsaline conditions with nanopure water $\left(\mathrm{G}_{\mathrm{H} 2 \mathrm{O}}\right)$ and germination obtained with the saline concentration $\mathrm{LD}_{50 \max }$. This germination is termed $\mathrm{GLD}_{50 \max }$, thus TE was determined through:

$$
\mathrm{TE}=\mathrm{G}_{\mathrm{H} 2 \mathrm{O}}-\mathrm{G}_{\mathrm{LD} 50 \max }
$$

Based on the values of TE and OE, the ionic effect (IE) was calculated:

$$
\mathrm{IE}=\mathrm{TE}-\mathrm{OE}
$$

\section{Statistical analysis}

A factorial design in randomized complete block $\left(B_{i}\right)$ was used in this study, with two factors: selections $\left(\mathrm{S}_{\mathrm{k}}\right)$ (Amarilla, Roja, Pucura and Hueque) and salinity $\left(\mathrm{C}_{\mathrm{j}}\right)(\mathrm{NaCl} 0 ; 0.2 ; 0.4 ; 0.8$ and $1.2 \mathrm{M})$. All the data were analyzed statistically using the variance test (ANOVA) with the INFOSTAT program (2004) 2007p version. The Duncan's test was using for multiple comparisons, with a $95 \%$ level of significance. The percentages were transformed into an arcsine through the equation described by Dughetti and García (2004). The correlations were determined through a principle component analysis.

\section{RESULTS AND DISCUSSION}

\section{Germination under non-saline conditions}

Under the non-saline conditions, all the selections present a sigmoid germination curve, with a first stage characterized by a low germination rate, which lasted until $6 \mathrm{~h}$ after seeding; an intermediate stage between 6 to $14 \mathrm{~h}$ with a maximum germination rate, and a final stage of an asintotic character in which the germination velocity increases minimally (Figure 1). All the selections reached $100 \%$ of germination, although at different times, which shows the good quality of the seeds used.

The seeds of the selection Amarilla were the most rapid to germinate, presenting in the first stage a rate of 6.9 germinated seeds per hour $\left(\right.$ seed $\left.\mathrm{h}^{-1}\right)$, reaching $41.6 \%$ germination at $6 \mathrm{~h}$ after seeding. This germination velocity is in contrast to that presented by the selection Hueque. The latter presented only 0.7 seed $h^{-1}$, reaching close to $3 \%$ of germinated seeds at the end of the same time (Figure 1). In this stage the selections Roja and Pucura presented intermediate values of 3.7 and 2.2 seed $\mathrm{h}^{-1}$, respectively.

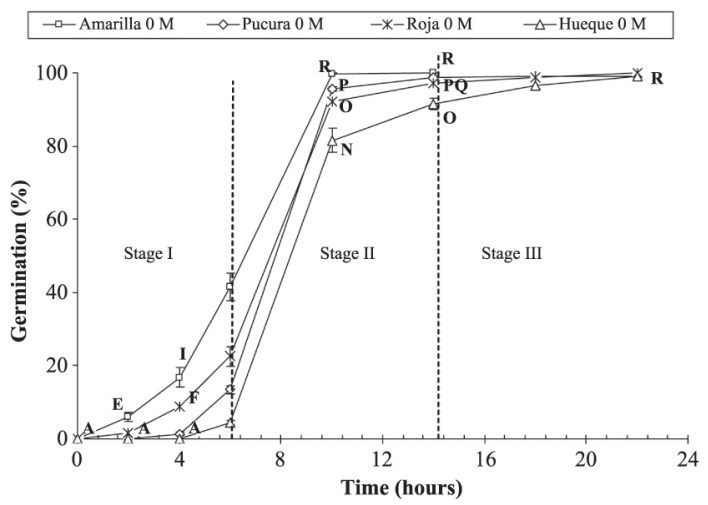

Average values of five replicates. Different letters indicate differences among the treatments $(\mathrm{P} \leq 0.05)$. Vertical bars indicate standard error $( \pm)$, very small values are not represented.

\section{Figure 1. Germination kinetics in four quinua selections under non-saline conditions ( $\mathrm{M} \mathrm{NaCl})$. Effect of salinity on germination.}

In the second stage of germination kinetics (between 6 and $14 \mathrm{~h}$ ), the differentials among the germination rates observed in the first stage tended to be lower. However, owing to the marked differences presented in the first stage, the percentages of germination between Amarilla and Hueque were significantly different $(\mathrm{P} \leq 0.05)$ at the end of the second stage $(14 \mathrm{~h})$. In effect, at the end of this stage the selection Amarilla reached $100 \%$ germination, while Hueque reached only $80 \%$. Research on seeds of cv. Sajama from the Bolivian salt flats, which were irrigated with distilled water, showed that this variety reached the maximum germination at $10 \mathrm{~h}$ (Prado et al., 2000), very similar results to those described by Jacobsen and Bach (1998), who worked under non-saline conditions with the 
var. Olav originating from southern Chile. Because $100 \%$ of Amarilla seeds germinated by $10 \mathrm{~h}$, the final phase of this selection was very short, while in Hueque it was prolonged to $22 \mathrm{~h}$ before reaching $100 \%$. For their part, the selections Roja and Pucura presented an intermediate behavior, reaching $100 \%$ of germination by $18 \mathrm{~h}$ (Figure 1).

As the concentration of salts in the saline solution increased (Figure 2), the percentages of germination decreased significantly in all the selections $(\mathrm{P} \leq 0.05)$. Comparing the final germination percentages (hour 22) among the seeds irrigated with saline solutions and the control treatments $(\mathrm{NaCl} 0 \mathrm{M})$, it can be observed that with $0.2 \mathrm{M} \mathrm{NaCl}$, the most affected selection was Hueque, which decreased germination by $51.2 \%$, while the decrease in Amarilla was only 6\%. With $0.4 \mathrm{M} \mathrm{NaCl}$, germination was more drastically reduced in all the selections $(\mathrm{P} \leq$ 0.05 ), Amarilla decreased by $53.8 \%$, Pucura by $63 \%$, Roja by $76.6 \%$ and Hueque, which was the most affected, by $90.2 \%$. Concentrations of $\mathrm{NaCl}$ above $0.8 \mathrm{M}$ inhibited germination in all the selections.

Salinity inhibited germination in the four selections of evaluated quinua. The selection Amarilla was the most tolerant, given that its germination was reduced by $53.8 \%$ in solutions of $0.4 \mathrm{M}$ of $\mathrm{NaCl}\left(\mathrm{LD}_{50 \mathrm{max}}\right)$, unlike Hueque, in which germination decreased by $89.4 \%$ (Figure 2). This reaffirms that of the four evaluated selections, the most tolerant to salinity is Amarilla from northern Chile and Andean salt flats. The most sensitive to salinity is Hueque, from the rainy non-saline region of southern Chile.

Based on the final germination data and considering $22 \mathrm{~h}$ after seeding as a limit, a period in which Hueque reached $100 \%$ germination in the control treatment, $\mathrm{LD}_{50}$ was estimated for each selection (Figure 3). According to these data, Hueque seeds decreased germination by $50 \%$ when $0.2 \mathrm{M} \mathrm{NaCl}$ was applied. For its part, Amarilla did the same when $0.4 \mathrm{M} \mathrm{NaCl}$ was applied. Germination in Pucura and Roja decreased by $50 \%$ with intermediate saline concentrations of 0.36 and $0.32 \mathrm{M}$ $\mathrm{NaCl}$, respectively.

These results confirm that the selection Hueque was the most sensitive to the total effect of salts (osmotic and ionic), with a low tolerance to salinity $\left(\mathrm{LD}_{50}=\mathrm{NaCl}\right.$ $0.2 \mathrm{M})$. For the accession that was most tolerant to salts, Amarilla, $\mathrm{LD}_{50}$ was at $0.4 \mathrm{M} \mathrm{NaCl}$ and consequently this salt concentration was used as $\mathrm{LD}_{50 \max }$. This concentration has been used empirically by other authors to induce saline stress in quinua (Prado et al., 2000), so that these results confirm this doses as a sub-lethal concentration
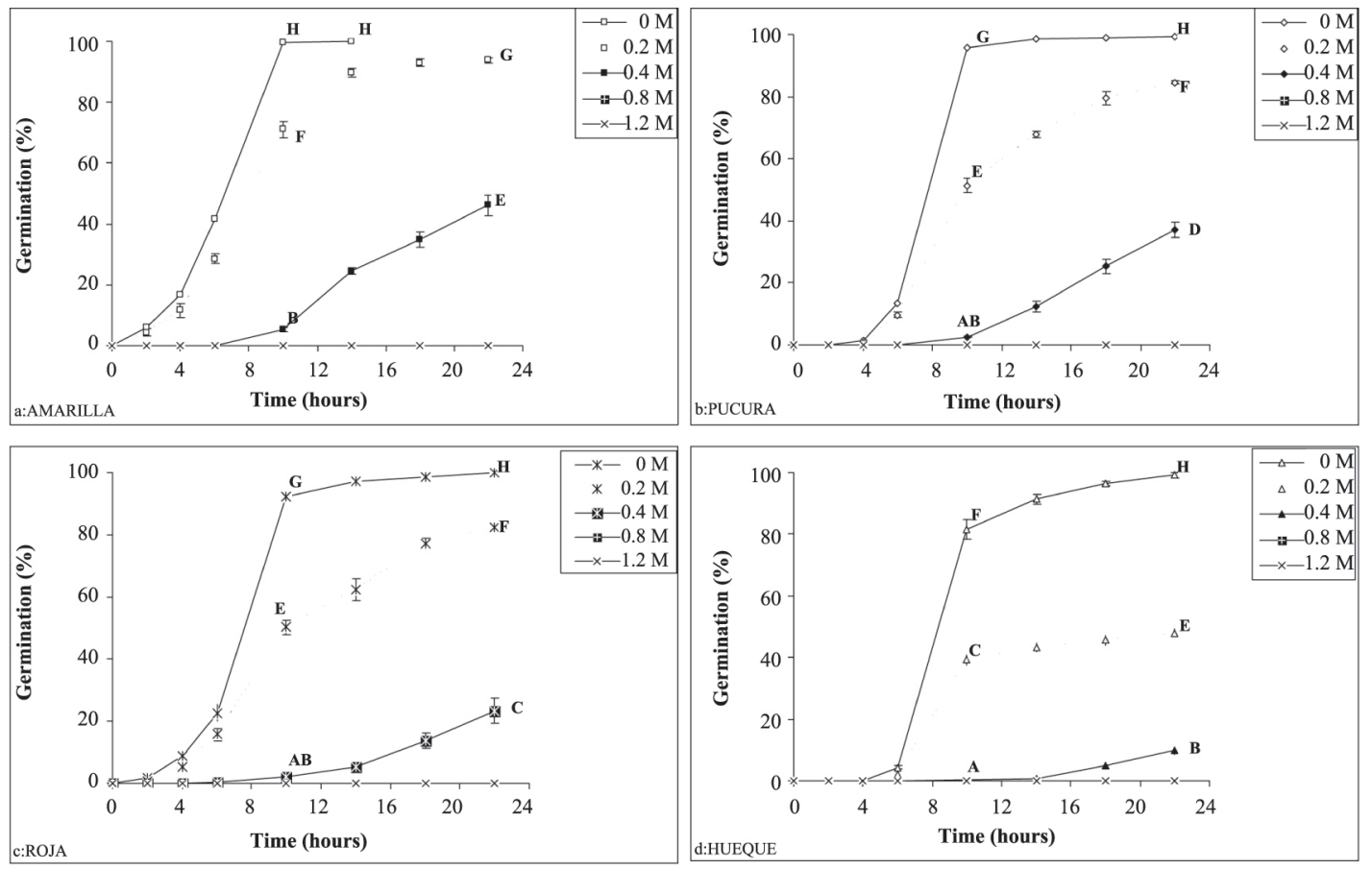

Different letters denote significant differences $(\mathrm{P} \leq 0.05)$. The values correspond to the average of five replicates. Vertical bars indicate standard error $( \pm)$; very small values are not represented.

Figure 2. Germination curves under different saline concentrations (0, 0.2, 0.4, 0.8 and 1.2 M NaCl). a) Amarilla; b) Pucura; c) Roja and d) Hueque. All values for 0.8 and $1.2 \mathrm{M}$ are 0 . Amarilla reached $100 \%$ in $12 \mathrm{~h}$, because of which data up to $22 \mathrm{~h}$ are not presented. 


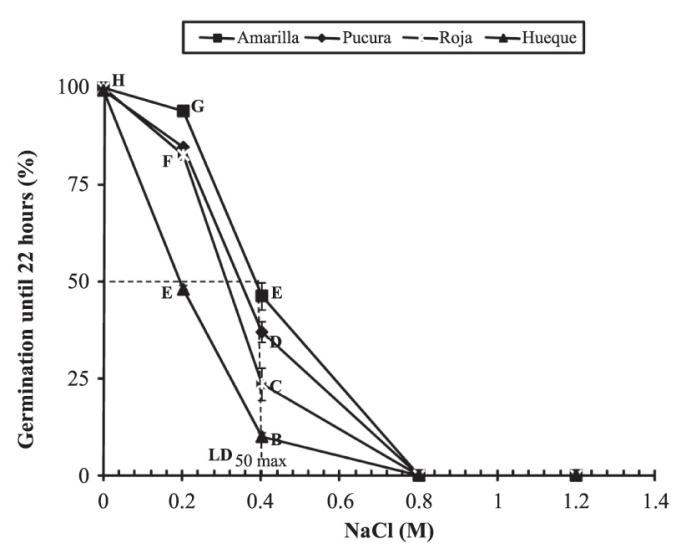

The data correspond to the final germination percentages independent of the time it was reached. The values correspond to the average of five replicates. The letters indicate significant differences in germination among treatments $(\mathrm{P} \leq 0.05)$. Vertical bars indicate standard error $( \pm)$; very small values are not represented.

Figure 3. Salinity effect on seed germination of four quinua selections. The values correspond to the average of five replicates. Dotted line parallel to $X$ axis represents $50 \%$ germination. Line parallel to $\mathbf{Y}$ axis represents saline concentration where $50 \%$ germination is obtained in the most tolerant selection (Amarilla) or $\mathbf{L D}_{50 \max }$.

that significantly affects germination of quinua seeds. In this respect, all the selections submitted to $\mathrm{LD}_{50 \max }(\mathrm{NaCl}$ $0.4 \mathrm{M}$ ) showed a considerable delay in germination. The selection Amarilla, for example, did not exceed 3.3 seeds $\mathrm{h}^{-1}$, while Hueque reached rates of only 0.7 seeds $\mathrm{h}^{-1}$.

\section{Separation of the component stressful factors of salinity}

Determination of the osmotic effect (EO) on the germination of quinua seeds. The data on germination using an iso osmotic solution equivalent to $0.4 \mathrm{M} \mathrm{NaCl}$ (658 mOsmol kg-1 or $-1.4 \mathrm{MPa}$ ) is presented in Figure 4. These results show that the selections Pucura, Amarilla and Roja presented very similar final germination percentages: $77.0 ; 73.8$ and $69.8 \%$, respectively. On the other hand, the selection Hueque was again the most affected by the osmotic potential of the solution (-1.4 $\mathrm{MPa}$ ), in that its germination was reduced by $49.6 \%$, which differed significantly from the other selections $(\mathrm{P} \leq 0.05)$. However, this data alone are not sufficient to determine if $\mathrm{OE}$ is the preponderant effect in the deterioration of germination of this selection. These results also show that all the selections under conditions of osmotic stress present a delay of $6 \mathrm{~h}$ in the velocity of germination compared to the control treatment. Nevertheless, this process advance germination by $4 \mathrm{~h}$ compared to that with $0.4 \mathrm{M} \mathrm{NaCl}$ (Figure 2), which shows the ionic effect

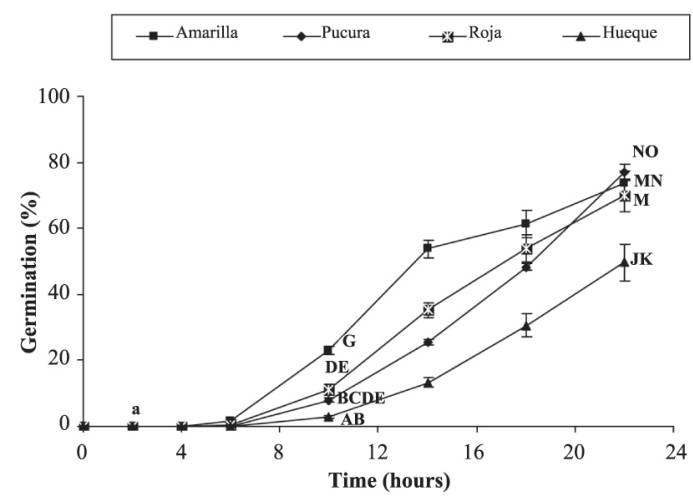

Different letters denote significant differences among treatments $(\mathrm{P} \leq 0.05)$. The values correspond to the average of five replicates. Vertical bars indicate standard error $( \pm)$; very small values are not represented.

Figure 4. Osmolality effect $\left(658 \mathrm{mOsmol} \mathrm{kg}^{-1}\right)$ of the irrigation solution on the germination of four quinua selections.

as the more influential as the osmotic in deteriorating germination. This is supported by data from Almansouri et al. (2001), who reported that the application in wheat of an iso-osmotic solution (1.57 MPa) of polietilenglycol (PEG) had a greater effect on germination than $\mathrm{NaCl}$ as a result of the reduced osmotic potential of the irrigation solution.

Influence of ionic effect on quinua seeds subjected to saline stress: To separate the osmotic and ionic effects, the percentages of germination obtained with nanopure water were used, with $\mathrm{NaCl} 0.4 \mathrm{M}\left(\mathrm{LD}_{50 \max }\right)$ and 658 mOsmol kg-1 of the equivalent iso osmotic solution (-1.4 $\mathrm{MPa}$ ). Based on these data, it is possible to determine that osmotic potential significantly influences $(\mathrm{P} \leq 0.05)$ the selection Hueque, provoking a $50 \%$ reduction in germination (Table 1). This could indicate that Hueque is a susceptible species to water deficit and that the osmotic effect in salinity stress has a major influence on its germination. Nevertheless, the ionic effect is not less important, given that it represents $40 \%$ of the decrease in germination of this selection. For their part, germination in Amarilla, Pucura and Roja is more affected by the ionic potential, with reductions in germination of between 51.3 and $64.5 \%$.

Notably, these results confirm that Hueque is susceptible to salinity, with both factors (osmotic and ionic) being equally important. On the other hand, the same analysis determines that Pucura and Roja are more influenced by the ionic factor (40\% and $46 \%$, respectively). Amarilla was shown to be the most tolerant given the low influence of the osmotic (26.2\%) and ionic factors $(27.6 \%)$ on germination. 
Table 1. Determination of the influence of osmotic and ionic factors of saline stress on seed germination in four quinua selections submitted to $0.4 \mathrm{M}$ of $\mathrm{NaCl}$.

\begin{tabular}{lccccc}
\hline Accession & Osmotic effect & $\begin{array}{c}\text { Total effect } \\
\text { (ionic + osmotic) }\end{array}$ & Ionic effect & $\begin{array}{c}\text { Ratio } \\
\text { (ionic effect/ } \\
\text { osmotic effect) }\end{array}$ & $\begin{array}{c}\text { Proportion } \\
\text { (ionic effect/ } \\
\text { total effect) }\end{array}$ \\
\hline & $26.2 \mathrm{ab}$ & $53.8 \mathrm{a}$ & $27.6 \mathrm{a}$ & & \\
Amarilla & $30.2 \mathrm{~b}$ & $76.6 \mathrm{c}$ & $46.4 \mathrm{~b}$ & 1.1 & 51.3 \\
Roja & $22.2 \mathrm{a}$ & $62.6 \mathrm{~b}$ & $40.4 \mathrm{~b}$ & 1.5 & 60.6 \\
Pucura & $50.0 \mathrm{c}$ & $90.0 \mathrm{~d}$ & $40.0 \mathrm{~b}$ & 1.8 & 64.5 \\
Hueque & & & 0.8 & 44.4 \\
\hline
\end{tabular}

The values correspond to the percentage of germination.

Different letters denote significant differences among treatments $(\mathrm{P} \leq 0.05)$. The values correspond to the averages of five replicates.

The osmotic effect reduced germination in Hueque by $50 \%$, while the ionic effect reduced it by $40 \%$. This indicates that in this case germination is affected by the availability of water than by the ionic effect. The glycophyte character of this selection might be a consequence of its acclimatization to non-saline environments with high precipitation.

Calculating the relative importance of the two stresses (osmotic and ionic), it is possible to determine that the two stressful factors have a proportional participation in the deterioration of germination in Amarilla and Hueque that is manifested as a ratio of 1.1 and 0.8 , respectively, differentiating them in the magnitude of the effect. For their part, germination of Pucura and Roja are more influenced by the ionic effect.

Based on the principle component analysis (PC) of the percentages of germination, we can infer that there is a correlation between ionic (EI) and osmotic effects (OE) in each selection. As there are only two variables (IE and OE) and the PCs are lineal combinations of these variables, it can be expected that PC explains $100 \%$ of the variation caused by the two effects.

Under this statistical procedure, the principle component 1 (PC1) explains $59.6 \%$ of the behavior and allows for determining that the selection Hueque is the most affected by saline stress of all the selections. Pucura and Roja presented an intermediate effect, while Amarilla was the most tolerant to salts. Nevertheless, the principle component 2 (PC2), which explains $40 \%$ of total variability, allows for differentiating the most susceptible and tolerant varieties in relation to the two stress factors. PC2 indicates that Hueque correlates positively with osmotic stress, while Amarilla is less influenced by ionic stress (IE).

Quinua germination was affected by both OE and IE independent of the accessions, which is in agreement with what was indicated by Poljakoff-Mayber et al. (1994). The analysis by osmotic and ionic factors (Table 1 ) shows that $\mathrm{OE}$ causes a 22 to $30.2 \%$ decrease in germination of in Amarilla, Pucura and Roja. This indicates that these selections can behave as pseudo-halophytes, consistent with what was found by Bosque et al. (2003). OE causes a decrease in water availability, affecting water intake and consequently germination, which is why the ionic phase is not manifested. This occurs in seeds of glycophyte plants that are affected by salts, such as wheat (Almansouri et al., 2001) and is similar to the situation of the accession Hueque, which comes form a non-saline region. Katambe et al. (1998) indicate that high concentrations of $\mathrm{NaCl}$ applied to seeds of halophyte plants, such as Atriplex prostrata, are more inhibiting of germination than isoosmotic applications of PEG. In this case, osmotic and ionic effects act together. Nevertheless, in this last point there are discrepancies, given that Song et al. (2005) indicates that both $\mathrm{Na}^{+}$and $\mathrm{Cl}^{-}$contribute to reducing the inhibiting effect of the osmotic potential of seeds of halophyte plants, raising the percentage of germination under saline conditions, as occurs in the selections Amarilla, Roja and Pucura. Khan and Ungar (1996) indicate, as well that the seeds of halophyte plants that do not germinate often enter dormancy. In this respect, Table 3 shows the percentage of seeds that germinate after having been submitted to different saline treatments, ratifying that Amarilla is more tolerant to salts, given that it recovered $23.1 \%$ of seeds that did not germinate owing to saline stress. Table 3 also shows that quinua seeds entered saline dormancy.

Analyzing the $\mathrm{Na}$ content, the main cause of the ionic effect is made evident by the ratio: final/initial $\mathrm{Na}$ concentrations (Table 2), in which the selections Amarilla and Roja, from the slat flats of the high Andes, show an increase in this ratio when they are submitted to $\mathrm{LD}_{50 \max }$ $(0.4 \mathrm{M} \mathrm{NaCl})$.

Thus, both Amarilla and Roja increased $\mathrm{Na}$ intake toward the end of the germination period $(22 \mathrm{~h})$ by 8.9 and 10.5 times, respectively, compared to its initial concentration. Nevertheless, Roja is more sensitive to salts than Amarilla, which is in agreement with what was indicated by Cramer et al. (1994), who found that higher intake of $\mathrm{Na}^{+}$in corn (Zea mays L.) does not correlate 
Table 2. Ratio between sodium absorbed at $22 \mathrm{~h}$ vs. initial sodium content in seeds germinated with 0 and $0.4 \mathrm{M} \mathrm{NaCl}$.

\begin{tabular}{|c|c|c|c|c|c|c|}
\hline \multirow[b]{2}{*}{ Selection } & \multirow[b]{2}{*}{ Initial value $T_{0}$} & \multicolumn{2}{|c|}{ Final value (T22) } & \multirow{2}{*}{$\begin{array}{c}\text { Differential } \\
\text { NaCl 0.4 M } \\
\text { T22-T0 }\end{array}$} & \multicolumn{2}{|c|}{ Ratios } \\
\hline & & $\mathrm{NaCl} 0 \mathrm{M}$ & $\mathrm{NaCl} 0.4 \mathrm{M}$ & & 0.4 M T22/T0 & $0.4 / 0$ M T22/T22 \\
\hline & $\mu \mathrm{g} \mathrm{Na} \mathrm{Ng}^{-1}$ seeds & 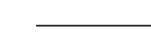 & $n g \mathrm{Na}^{+} \mathrm{g}^{-1}$ see & 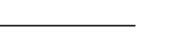 & & \\
\hline Amarilla & $35.0 \mathrm{a}$ & $51.6 \mathrm{ab}$ & 348.6de & 313.6 & 10.0 & 6.8 \\
\hline Roja & $85.6 b c$ & $45.8 \mathrm{ab}$ & $983.3 \mathrm{f}$ & 897.7 & 11.5 & 21.5 \\
\hline Pucura & $107.9 \mathrm{c}$ & $73.2 \mathrm{abc}$ & $310.9 d$ & 203.0 & 2.9 & 4.2 \\
\hline Hueque & $49.5 \mathrm{ab}$ & $42.6 \mathrm{ab}$ & $357.0 \mathrm{e}$ & 307.5 & 7.2 & 8.4 \\
\hline
\end{tabular}

T: measurements at 0 and $22 \mathrm{~h}$. Different letters denote significant differences among treatments $(\mathrm{P} \leq 0.05)$. The values correspond to averages of five replicates.

Table 3. Recovery of seed germination after salt stress.

\begin{tabular}{lcccc}
\hline \multirow{2}{*}{$\begin{array}{l}\text { NaCl }(\mathbf{M}) \\
\text { concentration }\end{array}$} & \multicolumn{4}{c}{ Accessions } \\
\cline { 2 - 5 } & \multicolumn{1}{c}{ Amarilla } & Roja & Pucura & Hueque \\
\cline { 2 - 5 } 0 & $0.00 \pm 0.00 \mathrm{e}$ & $0.00 \pm 0.00 \mathrm{e}$ & $0.00 \pm 0.00 \mathrm{e}$ & $0.00 \pm 0.00 \mathrm{e}$ \\
0.2 & $21.25 \pm 16.85 \mathrm{a}$ & $12.46 \pm 12.26 \mathrm{bc}$ & $14.52 \pm 10.31 \mathrm{~b}$ & $5.14 \pm 6.13 \mathrm{~d}$ \\
0.4 & $23.13 \pm 23.00 \mathrm{a}$ & $15.48 \pm 16.40 \mathrm{~b}$ & $7.86 \pm 9.64 \mathrm{~cd}$ & $4.28 \pm 5.06 \mathrm{de}$ \\
\hline
\end{tabular}

* Mean \pm standard deviation. Lower case letters indicate significant differences according to Duncan test $(\mathrm{P} \leq 0.05)$.

with salt tolerance, a situation that is observed with all the evaluated accessions. Management of $\mathrm{Na}$ in the tissues of tolerant species is controlled by the existence of mechanisms that allow for effective handling salts, such as the mobilization of ions to maintain ionic and osmotic homeostasis in the cells (Flowers et al., 1977; Hasegawa et al., 2000; Blumwald, 2000; Zhu, 2003).

\section{CONCLUSIONS}

Salinity affects the germination process in quinua seeds. However, the evaluated selections have different levels of tolerance to salts $(\mathrm{NaCl})$. The selection Hueque is considered the most sensitive, presenting a $50 \%$ seed loss $\left(\mathrm{LD}_{50}\right)$ with $0.2 \mathrm{M} \mathrm{NaCl}$, while Amarilla was the most tolerant, with an $\mathrm{LD}_{50}$ of $0.4 \mathrm{M} \mathrm{NaCl}$.

The components of salinity (osmotic and ionic effects) affect the evaluated quinua selections differently. Hueque was affected more proportionally by the osmotic effect, while Pucura and Roja are more affected by the ionic effect. The selection Amarilla, which was considered as the most tolerant, presented a low influence of both factors, in particular of the ionic effect.

\section{ACKNOWLEDGEMENTS}

The authors are grateful for the support provided by the Fundación para la Innovación Agraria (FIA) through the ProjectFIA-PI-C-2004-1-A-079, by FONDECYT through the Project $\mathrm{N}^{\circ} 1060281$, as well as the Department of Desert Agriculture and Biotechnology of the Universidad Arturo Prat, with special thanks to Alejandra Acevedo of the Physiology and Vegetal Nutrition Laboratory.

\section{RESUMEN}

Importancia de los componentes iónico y osmótico del estrés salino sobre la germinación de cuatro selecciones de quinua (Chenopodium quinoa Willd.). La influencia de los componentes del estrés salino (factores osmótico y iónico) fue evaluada durante la germinación en cuatro selecciones de quinua (Chenopodium quinoa Willd.), dos cultivadas en la zona árida y salina del altiplano (Amarilla y Roja) y dos en la zona húmeda y suelos no salinos en Chile (Hueque y Pucura). Las semillas fueron tratadas con diferentes concentraciones salinas $(\mathrm{NaCl} 0 ; 0,2 ; 0,4$; 0,8 y $1,2 \mathrm{M}$ ). Las cinéticas de germinación muestran que los tratamientos testigos de las cuatro selecciones alcanzan un $100 \%$ de germinación. Al aplicar $\mathrm{NaCl} 0,4$ $\mathrm{M}\left(\mathrm{LD}_{50 \max }\right)$, la germinación se reduce en un $53 \%$ en la línea Amarilla y $89,9 \%$ en Hueque. La velocidad de germinación fue menor en las semillas provenientes de selecciones de zonas no salinas, las que demoran $22 \mathrm{~h}$ en alcanzar el $100 \%$ de germinación, en comparación con las $10 \mathrm{~h}$ de Amarilla. Al separar los factores estresantes de la salinidad (osmóticos y iónicos) es posible concluir que éstos tienen diferentes magnitudes de influencia en la germinación de quinua, según cada selección. Así la 
germinación en la selección Amarilla de la zona árida fue la menos influenciada por el factor iónico (27\%), Pucura y Roja fueron más afectadas por el factor iónico (40\% y $46 \%$, respectivamente), en tanto que el factor osmótico influyó en un $50 \%$ en la pérdida de la germinación. en Hueque.

Palabras clave: Chenopodium, salinidad, imbibición, semillas, $\mathrm{NaCl}$, altiplano, desierto.

\section{LITERATURE CITED}

Almansouri, M., J.M. Kinet, and S. Lutts. 2001. Effect of salt and osmotic stresses on germination in durum wheat (Triticum durum Desf.). Plant Soil 231:243254.

Bayuelos, J., R. Craig, and J. Lynch. 2002. Salinity tolerance of Phaseolus species during germination and early seedling growth. Crop Sci. 42:1584-1594.

Blumwald, E. 2000. Sodium transport and salt tolerance in plants. Curr. Opin. Cell Biol. 12:431-434.

Bosque, H., P. Lemeur, P. Van Damme, and S.E. Jacobsen. 2003. Ecophysiological analysis of drought and salinity stress of quinoa (Chenopodium quinoa Willd.). Food Rev. Int. 19(1-2):111-119.

Cramer, G.R., G.J. Alberico, and C. Schmidt. 1994. Salt tolerance is not associated with sodium accumulation of two maize hybrids. Aust. J. Plant Physiol. 21:675692.

Debez, A., K.B. Hamed, C. Grignon, and C.H. Abdelly. 2004. Salinity effects on germination, growth and seed production of the halophyte Cakile maritime. Plant Soil. 262:179-189.

Delatorre, J., J. Arenas, y H. Campos. 1995. Comparación morfológica de nueve ecotipos de quinua (Chenopodium quinua) recolectados en el altiplano de la provincia de Iquique. Agricultura del Desierto (1):5-14.

Dodd, G., and L. Donovan. 1999. Water potential and ionic effects on germination and seedling growth of two cold desert shrubs. Am. J. Bot. 86:1146-1153.

Dughetti, A.C., y C. García. 2004. Prueba de la tolerancia de distintos materiales de cebolla de días largos, al ataque de Delia spp. (Diptera: Anthomyidae). p. 71. In XXVII Conferencia Congreso Argentino de Horticultura, VI Reunión Científica de la Cebolla del Mercosur. I Jornadas de Productos Frutihortícolas para una Alimentación Saludable, San Luis. 21-24 septiembre. Asociación Argentina de Horticultura (ASAHO), La Consulta, Mendoza, Argentina.

Flowers, T., P.F. Troke, and A.R. Yeo. 1977. The mechanisms of salt tolerance in halophytes. Annu. Rev. Plant Physiol. 28:89-121.
Fuentes, F., E. Martínez, J. Delatorre, P. Hinrichsen, E. Jellen, y J. Maughan. 2005. Diversidad genética de germoplasma chileno de quinua (Chenopodium quinoa Willd.) usando marcadores de microsatélites (secuencias simples repetidas, SSR). In Resúmenes de XXII Congreso Internacional de Cultivos Andinos, Instituto Nacional de Investigaciones Agropecuarias (INIAP), Quito, Ecuador.

Fuentes, F., E. Martinez, P. Hinrichsen, E.N. Jellen, and P.J. Maughan. 2008. Assessment of genetic diversity patterns in Chilean quinoa (Chenopodium quinoa Willd.) germplasm using multiplex fluorescent microsatellite markers. Conserv. Genet. doi: 10.1007/ s10592-008-9604-3.

Gul, B., and D. Weber. 1998. Effect of dormancy relieving compounds on the seed germination of non-dormant Allenrolfea occidentalis under salinity stress. Ann. Bot. (London) 82:555-560.

Hasegawa, P., R. Bressan, J. Zhu, and H. Bohnert. 2000. Plant cellular and molecular responses to high salinity. Annu. Rev. Plant Physiol. 51:463-499.

Huang, J., and R.E. Redmann. 1995. Salt tolerance of Hordeum and Brassica species during germination and early seedling growth. Can. J. Plant Sci. 75:815819.

Hunt, J. 1982. Dilute hydrochloric acid extraction of plant material for routines cation analysis. Commun. Soil Sci. Plant Anal. 13:49-55.

InfoStat. 2004. InfoStat versión 2004. Grupo InfoStat, FCA, Universidad Nacional de Córdoba, Argentina.

Jacobsen, S.E., and A.P. Bach. 1998. The influence of temperature on seed germination rate in quinoa (Chenopodium quinoa Willd.). Seed Sci. Technol. 26:515-523.

Jacobsen, S-E, E. Ruiz, A. Mujica, J.L. Christiansen, y R. Ortiz. 1999. Evaluación de accesiones de quinua para tolerancia a salinidad. 131 p. In Jacobsen, S.E., and A. Valdez (eds.) Primer Taller Internacional sobre Quinua - Recursos Genéticos y Sistemas de Producción, Libro de Resúmenes. 10-14 mayo. Universidad Nacional Agraria La Molina (UNALM), Lima, Perú.

Karyotis, T., C. Iliadis, C. Noulas, and T. Mitsibonas. 2003. Preliminary research on seed production and nutrient content for certain quinoa varieties in salinesodic soil. J. Agron. Crop Sci. 189(6):402.

Katambe, W.J., L.A. Ungar, and J.P. Mitchell. 1998. Effect of salinity on germination and seedling growth of two Atriplex species (Chenopodiaceae). Ann. Bot. (London) 82:167-175.

Kerepesi, I., and G. Galiba. 2000. Osmotic and salt stressinduced alteration in soluble carbohydrate content in wheat seedlings. Crop Sci. 40:482-487. 
Khan, M.A., and I.A. Ungar. 1984. Seed polymorphism and germination responses to salt stress in Atriplex triangularis. Bot. Gaz. (Chicago) 145:487-494.

Khan, M.A., and I.A. Ungar. 1996. Comparative study of chloride, calcium, magnesium, potassium, and sodium content of seeds in temperate and tropical halophytes. J. Plant Nutr. 19:517-525.

Mujica, A., S-E. Jacobsen, J. Izquierdo, y J.P. Marte. 2001. Resistencia a factores adversos de la quinua (Chenopodium quinoa Willd.). Ancestral cultivo Andino, alimento del presente y futuro. p. 162183. Organización de las Naciones Unidas para la Agricultura y la Alimentación (FAO), Universidad Nacional del Altiplano (UNA), Puno, Centro Internacional de la Papa (CIP), Santiago, Chile.

Munns, R., D. Schachtman, and A. Condon. 1995. The significance of a two-phase growth response to salinity in wheat and Barley. Aust. J. Plant Physiol. 22:561-569.

Poljakoff-Mayber, A., G.F. Somers, E. Werker, and J.L. Gallagher. 1994. Seeds of Kosteletzkya virginica (Malvaceae): their structure, germination, and salt tolerance. II. Germination and salt tolerance. Am. J. Bot. 81-54-59.
Prado, F., C. Boero, M. Gallardo, and J. González. 2000. Effect of germination, growth, and soluble sugar content in Chenopodium quinoa Willd. seeds. Bot. Bull. Acad. Sinica 41:27-34.

Pujol, J.A., J.F. Calvo, and L. Ramírez-Díaz. 2000. Recovery of germination from different osmotic conditions by four halophytes from south eastern Spain. Ann. Bot. (London) 85:279-286.

Song, J., G. Feng, C. Tian, and F. Zhang. 2005. Strategies for adaptation of Suaeda physophora, Haloxylon amnodendron and Haloxylon persicum to a salines environment during seed-germination stage. Ann. Bot. (London) 96:399-405.

Ungar, I.A. 1996. Effect of salinity on seed germination, growth, and ion accumulation of Atriplex patula (Chenopodiaceae). Am. J. Bot. 83:604-607.

Zhu, J.K. 2003. Regulation of ion homeostasis under salt stress. Curr. Opin. Plant Biol. 6:441-445. 